\title{
COMMENTARY
}

\section{Air pollution and human health}

Agus Dwi Susanto

Pollution is still the main environmental problem in the world. Air, water, soil, chemical, metal, and workrelated pollution are often found in the environment. Among these pollutants, air pollution is the most important cause of death. ${ }^{1}$ Air pollution is a complex mixture of gases and particles whose source and composition are varied by place and time. ${ }^{2}$ Air pollution has occurred since prehistoric times, which began when humans came to know fire. Concerns about the effects of air pollution have a long history. Complaints about its impact on human health and the environment were first voiced by the citizens of Athens and ancient Rome. During the industrial revolution, urban air quality deteriorated due to the widespread use of coal in factories in Britain, Germany, the United States, and other countries that were leading to a "smog era". Although there has been a major impact of air pollution on public health, various initial laws and regulations for controlling pollution are generally weak and ineffective. After the Great Smog air pollution in London in 1952, people became more aware of its detrimental impact on human health, so strict laws enforcement was made to reduce pollution. Therefore, cities in industrialized countries were cleaner. ${ }^{3}$

Air pollution is classified according to its source, chemical composition, size, and place of emission. Classification of air pollution by source is divided into primary and secondary. Primary pollutants are released directly from certain sources into the atmosphere. The examples of primary pollutants are sulfur dioxide $\left(\mathrm{SO}_{2}\right)$, carbon monoxide ( $\left.\mathrm{CO}\right)$, and particulate matter (PM). Meanwhile, secondary pollutants are the result of chemical reactions between primary pollutant and gases. Examples of secondary pollutants are ozone $\left(\mathrm{O}_{3}\right)$ and nitrogen dioxide $\left(\mathrm{NO}_{2}\right)$. Classification of air pollution based on the place of emission is divided into outdoor and indoor air pollution. Classification of pollutants based on chemical composition and size of pollutants is divided into gases and particles (PM). ${ }^{4}$ The source of air pollution can be from nature and human activities including combustion or dissemination of dust. Natural events that contribute to pollution include volcanic activity, forest fires, and storms. The main sources of anthropogenic air pollution are the act of industrialization and urbanization, and it includes emissions from vehicles, factories, and power plants. Activities at home also become a source of air pollution such as cooking and heating in the house with fossil fuels (charcoal) and biomass (wood, animal dung, and crop wastes) on an open fire or traditional stoves. ${ }^{5}$

The World Health Organization (WHO) notes that currently $92 \%$ of the world's population breathe poor air quality. ${ }^{6}$ Numerous long-term studies related to air pollution show that people living in more polluted areas have a greater risk of premature death compared to residents living in regions that have lower air pollution.2 Globally, in 2015 there was an estimation of 9 million premature deaths due to pollution. This number is three times higher than the accumulated deaths from acquired immunodeficiency syndrome, tuberculosis, and malaria. ${ }^{1}$ WHO data records that there are 7 million deaths each year related to outdoor air pollution and indoor air pollution. ${ }^{7}$ Currently, air pollution is a major environmental problem. ${ }^{3}$ Air pollution is now clearly proven to be an important global risk factor for disease. Research in the last decade in many cities around the world shows that death linked to air pollution increased as the increasing air pollution level. Some studies have also shown in detail the effects of air pollution on human health. ${ }^{2}$ Air pollution can negatively impact the respiratory or pulmonary system, cardiovascular system, digestive system, skin, reproductive system, and cancer. ${ }^{8}$

Short-term or acute air pollution exposure is associated with the increase of respiratory symptoms, doctor and emergency visits, asthma medications usages, asthma attacks, heart attacks, hospital care, 
and risk of death. ${ }^{9}$ Long-term exposure to air pollution is also associated with health problems, especially respiration, such as acute respiratory infections, decreased lung function, asthma, chronic obstructive pulmonary disease (COPD), lung cancer, pulmonary fibrosis, cardiovascular disease, and cerebrovascular disease. ${ }^{4}$ In the respiratory system, WHO data shows that air pollution around the world contributes $29 \%$ of all diseases and deaths from lung cancer, $17 \%$ of all diseases and deaths due to acute respiratory infections, and $43 \%$ of all diseases and deaths due to COPD. ${ }^{10}$ Infection in the respiratory system is the most frequent health impact due to air pollution that comes from natural events and human activities. Burhan et al ${ }^{11}$ mentioned that air pollution increased due to forest fires and volcanic activity. The increase in pollutants has implications for the lung and respiratory immune system, and this increases the growth of bacteria. These conditions explain the increase of infections in the respiratory system due to air pollution from fire smoke and volcanic ash. ${ }^{11}$ Besides, the risk of lung cancer due to air pollution is associated with PM. In 2013, PM was classified as a cancer-causing ingredient by the WHO's International Agency for Research on Cancer. ${ }^{10}$ Morbidity and mortality of air pollution associated with lung cancer are in line with an increase of PM2.5 level through epigenetic and microenvironmental changes. The possible mechanism is the activation of tumorassociated signaling pathway mediated by microRNA dysregulation, DNA methylation, and an increase in the number of cytokines and inflammatory cells. ${ }^{8}$

Air pollution is a serious problem in Indonesia today, and this condition causes 50\% morbidity in all parts of Indonesia. ${ }^{12}$ Several studies in Indonesia show that air pollution is related to lung and respiratory health problems. The acute impact of air pollution due to smoke from forest fires in Sumatera, Indonesia in 2015 showed an increase in respiratory symptoms by $71.4 \%$ and decreased lung function by $72.6 \%{ }^{13}$ Study in 2015 found a prevalence of COPD in non-smokers in Indonesia was $6.9 \%$. One of the main factors in COPD non-smokers in Indonesia is exposure to indoor and outdoor air pollution. ${ }^{14}$ In 2002, WHO estimated COPD deaths related to the use of solid fuels (for populations over 30 years old) in Indonesia around 12,160 people. ${ }^{12}$ Regarding data on air pollution and lung cancer in Indonesia, a study in Persahabatan Hospital and Dharmais Hospital showed $4 \%$ of lung cancer cases were related to air pollution in 2013..$^{15}$
Air pollution is reported to be associated with cardiovascular and cerebrovascular diseases. The risk of this diseases is associated with PM with size of less than 10 and 2.5 microns (PM10 and PM2.5). PM can penetrate the airway and alveoli and then enter the blood vessels causing cardiovascular and cerebrovascular disorders. According to WHO data, air pollution worldwide is contributed to $24 \%$ of all deaths from stroke, $25 \%$ of all deaths and illnesses from ischemic heart disease. ${ }^{10} \mathrm{~A}$ meta-analysis shows that each increase of $10 \mu \mathrm{g} / \mathrm{m}^{3}$ in $\mathrm{PM} 2.5$ is associated with an absolute increase of $0.63 \%$ of cardiovascular mortality. ${ }^{16}$ According to another metaanalysis, all air pollution (except $\mathrm{O}_{3}$ ) was identified as a potential factor contributing to myocardial infarction, with an increase in daily relative risk of $0.7 \%$ and $1.7 \%$ per $10 \mu \mathrm{g} / \mathrm{m}^{3}$ increase in PM10 and PM2.5. ${ }^{17}$ Long-term exposure to air pollution is also associated with chronic ischemic heart disease and heart failure, especially patients with a history of coronary artery disease. ${ }^{18}$ Higher risk of atrial fibrillation when exposed to air pollution such as PM2.5 is also reported. ${ }^{17}$ A growing body of evidence has raised concerns about the harmful effects of pollutants inhaled over the past decade in the central nervous system. ${ }^{19}$ Several studies have shown that PM, NO, and $\mathrm{CO}$ pollutant exposures are associated with increased hospital visits and increased stroke mortality. ${ }^{20}$ Cohort study of the Women's Health Initiative in postmenopausal women found daily $\mathrm{NO}_{2}$ and NOx exposure associated with a high risk of hemorrhagic stroke. Moreover, the ambient levels of $\mathrm{PM} 10, \mathrm{PM}_{2} .5, \mathrm{SO}_{2}$, and $\mathrm{O}_{3}$ are not associated with stroke risk (hemorrhagic stroke and ischemic stroke). ${ }^{21}$

WHO states that air pollution affects pregnant women, fetuses, and children. Ambient air pollution exposure is associated with adverse birth outcomes, such as low birth weight, pre-term births, fetal death and small gestational age births, and neurodevelopmental

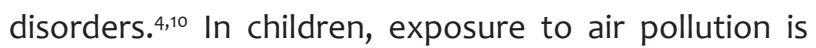
associated with the risk of acute respiratory infections, decreased lung function, risk of cancer, mental and motor development disorders, and cognitive disorders in children and adolescents. ${ }^{4}$ Stunting in children needs attention because it has to do with exposure to air pollution. A review by Pun et $\mathrm{al}^{22}$ in 2019 reported that an increase of up to $13 \%$ of stunting in children was associated with an increase in ambient air pollution exposure, and an increase in up to $90 \%$ stunting in children was associated with an increase in household air pollution. 
Indonesian Society of Respirology at media conference in 2019 stated that air pollution has proven implied human health including respiratory or pulmonary system, cardiovascular system, cerebrovascular system, cancer risk, and woman and children's health. To minimize the effect of air pollution especially outdoor air pollution on human health, the participation from all stakeholders are needed. Prevention is a major aspect that should be done to minimize the effect of air pollution on human health. ${ }^{23}$ Some of the prevention activities were making regulations to reduce air pollution emission including regulation of no-smoking area, regulation of threshold limit values for vehicle emissions, emission monitoring, maintenance for vehicle, enforcement for industrial emission, project on mass rapid transportation in some big cities, and increasing energy from renewable source. To protect human health from air pollution, further research is being conducted on health vulnerability. Collaboration between professional organization, non-governmental, and governmental organization on media educations, workshops, and symposiums need to be done to increase people awareness of air pollution.

From President of Indonesian Society of Respirology; Department of Pulmonology and Respiratory Medicine, Faculty of Medicine, Universitas Indonesia, Persahabatan Hospital, Jakarta, Indonesia pISSN: 0853-1773 • elSSN: 2252-8083

https://doi.org/10.13181/mji.com.204572

Med J Indones. 2020;29:8-10

Corresponding author:

Agus Dwi Susanto

E-mail: agus_ds2000@yahoo.com

\section{REFERENCES}

1. Pasqua LA, Damasceno MV, Cruz R, Matsuda M, Martins MG, Lima-Silva $A E$, et al. Exercising in air pollution: the cleanest versus dirtiest cities challenge. Int J Environ Res Public Health. 2018;15(7):1502.

2. Health Effects Institute. State of global air 2017: special report. Boston: Health Effects Institute; 2017. p. 1-15.

3. Mosley S. Environmental history of air pollution and protection [Internet]. Encyclopedia of Life Support Systems (EOLSS). 2019 [cited 2019 Aug 16]. Available from: https://www.eolss.net/ Sample-Chapters/Co9/E6-156-15.pdf.

4. Susanto AD, Fitriani F, Astuti TW, Antono W, Purwitasari M, Ikhsan $M$, et al. Prevention and treatment of health effects due to outdoor air pollution. The Indonesian Society of Respirology. Jakarta. 2019. Indonesian.

5. North CM, Rice MB, Ferkol T, Gozal D, Hui C, Jung SH, et. al.
Air pollution in the Asia-Pacific region: a joint Asian Pacific Society of Respirology/American Thoracic Society perspective (republication). Respirology. 2019;24(5):484-91.

6. Kirby T. WHO: $92 \%$ of the world's population breathe polluted air. Lancet Respir Med. 2016;4(11):P862.

7. World Health Organization. Air pollution infographic [Internet]. World Health Organization. 2019 [cited 2019 Aug 8]. Available from: https://www.who.int/airpollution/infographics/en/.

8. Li T, Hu R, Chen Z, Li Q, Huang S, Zhu Z. Fine particulate matter $\left(\mathrm{PM}_{2.5}\right)$ : the culprit for chronic lung diseases in China. Chronic Dis Transl Med. 2018;4(3):176-86.

9. United States Environmental Protection Agency. How BenMAPCE estimates the health and economic effects of air pollution [Internet]. United States Environmental Protection Agency. 2019 [cited 2019 Aug 10]. Available from: https://www.epa. gov/benmap/how-benmap-ce-estimates-health-and-economiceffects-air-pollution.

10. World Health Organization. Ambient air pollution: health impact. Geneva: World Health Organization; 2020 [cited 2020 Jan 21]. Available from: https://www.who.int/airpollution/ ambient/health-impacts/en/.

11. Burhan E, Mukminin U. A systematic review of respiratory infection due to air pollution during natural disasters. Med J Indones. 2020;29(1):11-8.

12. Haryanto B. Climate change and urban air pollution health impacts in Indonesia. In: Akhtar R, Palagiano C, editors. Climate change and air pollution. Cham: Springer Climate; 2018. p. 21539.

13. Zaini J, Susanto AD, Samoedro E, Bionika VL, Antariksa B. Health consequences of thick forest fire smoke to healthy residents in Riau, Indonesia: a cross-sectional study. Med J Indones. 2020;29(1):58-63.

14. Nguyen Viet N, Yunus F, Nguyen Thi Phuong A, Dao Bich V, Damayanti T, Wiyono $\mathrm{WH}$, et al. The prevalence and patient characteristics of chronic obstructive pulmonary disease in nonsmokers in Vietnam and Indonesia: an observational survey. Respirology. 2015;20(4):602-11.

15. Andarini S, Prayogo N, Susanto AD, Agustini S, Megawati, Elvira, et al. Final report of study and guideline on prevention, diagnosis and surveillance of occupational and environmental cancers in Indonesia. Jakarta; 2013.

16. Chin MT. Basic mechanisms for adverse cardiovascular events associated with air pollution. Heart. 2016;101(4):253-6.

17. Combes A, Franchineau G. Fine particle environmental pollution and cardiovascular diseases. Metabolism. 2019;100S:153944.

18. Warburton DER, Bredin SSD, Shellington EM, Cole C, de Faye A, Harris J, et al. A systematic review of the short-term health effects of air pollution in persons living with coronary heart disease. J Clin Med. 2019;8(2):274.

19. Brook RD, Rajagopalan S, Pope CA 3rd, Brook JR, Bhatnagar $A$, Diez-Roux AV, et al. Particulate matter air pollution and cardiovascular disease: an update to the scientific statement from the American Heart Association. Circulation. 2010;121(21):2331-78.

20. Lee KK, Miller MR, Shah ASV. Air pollution and stroke. J Stroke. 2018;20(1):2-11.

21. Sun S, Stewart S, Eliot MN, Yanosky JD, Liao D, Tinker LF, et al. Short-term exposure to air pollution and incidence of stroke in the Women's Health Initiative. Environ Int. 2019;132:105065.

22. Pun V, Mehta S, Dowling R. Air pollution and child stunting a systematic review and meta-analysis. Environ Epidemiol. 2019;3:318.

23. Perhimpunan Dokter Paru Indonesia (Jakarta, Indonesia). Press release "Perhimpunan Dokter Paru Indonesia (PDPI) menyikapi polusi udara di kota Jakarta” (Indonesia). 2019 Jul 31. 